\title{
DE USUNDE
}

Sundhedsantropologens møde med multisyge ældre på Lolland

\section{ALEXANDRA RYBORG JØNSSON}

„Medicinsk antropologi befinder sig i udkanten af lægevidenskaben, men også i udkanten af antropologien." Kleinmans berømte ord (Kleinman 1995:1; min oversættelse, ARJ) sætter rammen for mit feltarbejde, som jeg her vil bruge som udgangspunkt for en (selv)kritik af mødet mellem antropologisk vidensproduktion og dominerende sundhedsdiskurser. Jeg vil i denne artikel introducere en forskningsposition, som jeg kalder empatisk vidensproduktion. Med empatisk refererer jeg til antropologiens ansvar for at gøre lokale praksisser, erfaringer og udsagn forståelige i deres kontekst. Denne tilgang er inspireret af kritikken af den ,ontologiske vending“ “ i antropologien (se fx Sausdal \& Vigh 2013; Hastrup 2013; Højbjerg 2013), en kritik, der som antropologiens modus operandi fremhæver fokus på det situationelle i menneskers eksistens (Sausdal \& Vigh 2013: 116). Feltarbejde, samtaler og deltagelse i dagligt liv med mænd, kvinder og børn har i min optik til formål at vise forskelligheder i måden, mennesker lever på, i en specifik sociokulturel og politisk kontekst. Men med den medicinske antropologis positionering i udkanten af medicinsk forskning opstår en række etiske dilemmaer i forsøget på at kaste lys på vores informanters levede liv. Som medicinske antropologer interesserer vi os eksempelvis for måden, hvorpå lokale sociokulturelle faktorer spiller en rolle med hensyn til at monitorere kroppen og forstå symptomer (se fx Oxlund \& Whyte 2014). Antropologer fungerer altså i den medicinske forskning som fortolkere af menneskelig sundhedsadfærd, der viser, hvorfor og hvordan mennesker gør, som de gør (Brown \& Inhorn 1996: 198). Problemer i sundhedsantropologisk forskning skyldes ofte, at medicinsk antropologi og biomedicin er tæt sammenvævet, og som Lorna Rhodes påpeger (Rhodes 1996:159), arbejder mange antropologer i dag godt nok i udkanten af, men i biomedicinske settings eller studerer problemer, der er defineret i biomedicinske termer. Eksempelvis diskuterer Sharon Kaufman og Lakshmi Fjord, hvordan Medicare, den gratis, amerikanske sundhedsforsikring for de fattigste 
amerikanere, skaber en forestilling om, hvordan de syge skal leve, manifesteret i beslutninger om, hvilken behandling leversyge tilbydes (Kaufman \& Fjord 2011:212). Men de to forskere berører ikke etiske problemstillinger i deres egen positionering i biomedicinen. Opmærksomheden findes dog: I en dansk kontekst diskuterer eksempelvis Mette Nordahl Svendsen nødvendigheden af kritisk engageret forskning, idet hun viser, hvordan modstand fra informanter, som et vilkår i vidensproduktion, kan bruges produktivt til at gøre en eventuel kritisk position empirisk forankret. Ved at blotlægge epistemologiske forskelle mellem forsker og informanter tydeliggøres eventuelle modsatrettede interesser (Svendsen 2009). Stærkt inspireret af Svendsens diskussion af „kritisk engageret forskning" er det min intention at koble biomedicinske forforståelser op på min egen forskning og metode.

Artiklen her fokuserer på empatisk vidensproduktion i forhold til studier af, hvordan mennesker forstår og omsætter sundhedsbudskaber. Empatisk vidensproduktion er tænkt som et analytisk udgangspunkt for overvejelser over, hvilke konsekvenser dominerende biomedicinske diskurser i sundhedsforskningen har for det antropologiske projekt. Som det vil blive tydeligt i det følgende, er mine etiske refleksioner opstået over tid og i interaktion med både de mennesker, hvis liv jeg fulgte og her beskriver, og i samproduktion med kolleger og antropologiske forskningsfelter om sundhed, etik og ontologi. Hvordan og hvortil skal vi styre den analytiske opmærksomhed mellem vores biomedicinske samarbejdspartneres forventninger om, at vi kan identificere sundhedsbarrierer i vores empiriske objekters livsverdener? I artiklen her vil jeg argumentere for, at empatisk vidensproduktion kunne være et svar.

Undervejs vil jeg fremhæve den gradvise erkendelse af min positionering, som opstår i feltarbejdet, og vise, hvordan min stigende kritiske bevidsthed fører til en ny indsigt om etik i studiet. Jeg vil argumentere for, at der i sundhedsforskning ligger et moralsk imperativ, ved at vise, hvordan den biomedicinske forståelse af sundhed gennemsyrer mit projekt. Ved at fremhæve, hvordan min repræsentation ubevidst påvirkes af denne biomedicinske forståelse, viser jeg, dels at studier i eget samfund (også) kræver en konstant refleksion over skabelsen af det empiriske objekt, og dels at det analytiske objekt ofte skabes af forskellige aktører med modsatrettede interesser, og at antropologen ubevidst kan komme til at producere viden for snarere end om. Jeg vil således vise, hvordan jeg et godt stykke inde i feltarbejdet stadig fokuserer på rygning, kost og motion, en viden, som efterspørges af min opgavestiller, snarere end at finde frem til det, der egentlig har betydning for mine informanter, når det kommer til en hverdag med multisygdom. ${ }^{1}$ Disse indsigter lader jeg danne baggrund for en mere generel diskussion af etik i sundhedsantropologien, og jeg vil, bevidst provokerende og selvudstillende, sætte dem som analytisk ramme. 


\section{Broen til bedre sundhed}

Danmark har en række geografiske yderområder med socioøkonomiske udfordringer og en dårlig sundhedsprofil. Yderområder er karakteriseret ved lav erhvervsindkomst og svag befolkningsudvikling. 16 ud af de 98 danske kommuner kategoriseres sammen med småøerne som yderområder, svarende til 11 procent af Danmarks befolkning (Erhvervsstyrelsen 2016). Lolland er en af de lavest rangerende kommuner, når man måler på levetid, indkomst og uddannelsesniveau, og har relativt høj arbejdsløshed og høj forekomst af kroniske sygdomme (Region Sjælland 2016a). Statistisk set er Lolland en af de socioøkonomisk mest udfordrede kommuner i Danmark og har på grund af sin demografiske sammensætning en større andel af multisyge end gennemsnittet. Det er derfor oplagt, at mit feltarbejde foregår på Lolland, for multisygdom, som jeg undersøger, stiger med alderen og forekommer oftere blandt mennesker med en ufaglært, faglært eller kort boglig uddannelse end blandt højtuddannede (Larsen et al. 2013).

Som følge af den ringe sundhedsprofil er „bedre sundhed til flere borgere“ et regionalt mål for Lolland og Falster de kommende år. Der laves befolkningsundersøgelser, målprogrammer og indsatser og forskes blandt andet i livsstil, familierelationer og ældre. Mit ph.d.-projekt om hverdagsliv med kronisk sygdom er en del af denne storstilede indsats, der på sigt skal kunne forbedre den lokale befolknings sundhedstilstand. I mit studie ser jeg på, hvordan ældre mennesker med multisygdom håndterer sygdomsbyrde og behandlinger i hverdagen. Jeg undersøger, hvordan de navigerer i ofte modsatrettede behandlingsforløb, og hvordan dagligdagen tager sig ud, når man derfor hele tiden skal prioritere mellem at følge den ene eller den anden læges råd eller simpelthen helt lade være. Gennem 18 måneder har jeg besøgt, interviewet og brugt tid sammen med syv kvinder og syv mænd i alderen 66-90 med forskellige kombinationer af mere eller mindre behandlingskrævende kroniske sygdomme. Feltarbejdet, der fandt sted på Lolland i 2015-2016, er et samarbejde mellem Videnscenter for Brugerinddragelse i Sundhed og Forskningsenheden for Almen Praksis. ${ }^{2}$ Men hvem har retten til at definere et sundt liv, og hvad stiller man op med sin forskning, når man indser, at man er fanget i modsatrettede interesser?: opgavestillernes ønske om at bedre den biomedicinske sundhed versus de mennesker, som ikke kan eller vil forbedre denne sundhed.

Jeg er tilkoblet Lolland-Falster Undersøgelsen (LOFUS), der er det mest omfattende befolkningsstudie i et landområde i Danmark nogensinde med op mod 100 forskere tilknyttet. LOFUS arbejder også sammen med programmet „Broen til Bedre Sundhed“, et udviklingsprogram i Region Sjælland, der går ud på at skabe mere sundhed og mindre ulighed på Lolland og Falster. Broen til Bedre Sundhed er et samarbejde mellem kommuner, region, erhvervsliv og praktiseren- 
de læger på Lolland og Falster. Broen kan også forstås helt bogstaveligt som Farøbroerne, der forbinder Sjælland med Lolland og Falster, og som har fragtet mig og en række andre forskere „ned“ for at undersøge, hvordan vi forbedrer den lokale befolknings sundhedstilstand. Vi er brikker i et større politisk spil, der, uden at jeg her vil så tvivl om intentionerne, arbejder bevidst på at ændre adfærd hos dem, som er karakteriseret som usunde (Region Sjælland 2016a, 2016b). Det, at der er et $v i$, som arbejder for at skabe bedre sundhed på Lolland, konstruerer en Anden, der er uansvarlig, usund og forskellig fra, hvad der igen fremstilles som et homogent $o s$. Den viden, jeg finder frem til, er således moralsk konstitueret, hvilket leder mig frem til spørgsmålet om, hvem der har retten til at definere, hvad der er sundt.

\section{Forskningsetik - for hvem?}

For mere end 1600 år siden blev Skt. Augustins mor stillet over for det dilemma, som mange sundhedsantropologer møder i deres feltarbejde. Skt. Monica spørger: „I Rom faster de om lørdagen, men ikke i Milano, der faster de om søndagen. Hvad er det rigtige at gøre?“" Skt. Ambrosius svarer: „Når jeg er i Milano, gør jeg, som de gør i Milano, men når jeg er i Rom, gør jeg, som de gør i Rom“ (Brev 54, § 3; min oversættelse, ARJ; se Sparrow-Simpson 1919:281). Jeg oplevede dilemmaet i min egen etik og mine deltageres, når de åbenlyst ignorerede biomedicinske behandlinger. En kvindelig deltager ville ikke sove med sin iltmaske. Hun syntes, den var besværlig at tage af og på, og at den ødelagde hendes humør. Jeg syntes, det var et forkert valg, fordi hun blev sløv om dagen, og hendes sygdomme blev forværret. Hvad var det rigtige at gøre?

Etiske problemstillinger, der relaterer til individets omsorg for sig selv og socialt sanktionerede normer, er en velkendt udfordring i antropologiske feltarbejder. Det er forsøgt løst med forskningsretningslinjer, der skal hjælpe forskeren til at forholde sig kritisk til egen positionering. Dette forekommer dog utilstrækkeligt, idet forskningsetik stadig fremstilles som en institutionaliseret, normativ tilgang mere end en praksis mellem mennesker; forsker og deltager (Davis 2010:15-17). Individets frie respons på forskrifter om, hvad det bør gøre, såsom behandlingsplaner, er i sig selv etiske handlinger, ifølge Michel Foucault, fordi mennesket ved at drage omsorg for sig selv søger det bedste for sig selv: „Etik er bevidst ageren i frihed“"(Foucault 1988:18; min oversættelse, ARJ). Men jeg oplevede undervejs i feltarbejdet at undskylde mine normative moraliserende perspektiver over for mig selv med en etisk agenda om at „hjælpe“ mine informanter. Selv om „hjælpen“ ikke var bogstavelig, havde den en virkning i min tilgang. Jeg spørger i et interview kvinden med iltmasken: „Ville det ikke være bedre at 
være frisk, selv om den [iltmasken] er lidt besværlig?" Gennemlæsning af transskriptionen af dette interview fik mig til at reflektere over, hvad jeg konkret forstår ved forskningsetik. Godt hjulpet på vej af allerede eksisterende diskussioner (se fx Hastrup 2004b; Baarts 2009; Davis 2010) vil jeg derfor påstå, at antropologisk forskningsetik handler om, hvordan vi producerer meningsfuld viden om lokale former for levet liv, og hvordan sundhedspraksisser udfolder sig i konkrete sociale situationer. Svaret lå allerede i Skt. Ambrosius' svar: Vi skal forstå handlinger i deres lokale kontekst. Kirsten Hastrup pointerer netop, at vores etiske forpligtelse ligger $i$ en epistemologisk repræsentation af informanters verden (Hastrup 2004b:469). Hermed opstiller hun et etikbegreb, der ikke er ontologisk, fordi det ikke nøjes med at beskrive oplevelsen af væren-i-verden, og derfor indeholder magt, fordi det teoretiserer informanters agens og modstand, som ikke nødvendigvis er tydelig for dem, vi studerer (ibid.). For magten, biopower, altså måden, samfundet kontrollerer sundhed og sygdom i befolkningen på (Foucault 1979 [1976]), findes i relationen mellem stat og borger, antropolog og subjekt. Her er mit ærinde ikke en diskussion af magten, men blot at anerkende, at det er relevant med refleksioner i det biomedicinske felt over sundhedsproblemstillingers sociopolitiske indlejring. I stedet vil jeg igen følge Hastrups opfordring og advokere for et etisk standpunkt, hvor vi anerkender de gensidige implikationer mellem etik og epistemologi (Hastrup 2004b:470). Ved at positionere mit projekt som empatisk sætter jeg en etisk forpligtelse op for mig selv og mine medforskere til at tydeliggøre erfaringer, oplevelser, fortællinger og praksisser, ikke kun gennem beskrivelser, men også gennem teori og fortolkning, der stadig er tro mod informanternes virkelighed.

\section{Multisygdom som forskningsfelt}

Har man mere end to kroniske eller langvarige sygdomme på en gang, er man det, der kaldes ,multisyg“. Mennesker med multisygdom har nedsat livskvalitet (Nöel et al. 2005), og hverdagen med flere kroniske sygdomme bliver belastet af smerter, nedsat bevægelighed og tid, der skal bruges på behandlinger (Ørtenblad, Jønsson \& Meillier 2015; Høstrup \& Jønsson 2017). Har man først én kronisk sygdom, er risikoen for at udvikle nye forhøjet (van den Akker et al. 1998), og multisyge dør tidligere end gennemsnittet (Tinetti et al. 2011). Multisygdom er også forbundet med en større sygdomsbyrde, fordi man har flere sygdomme på én gang, og det kræver komplekse behandlingsstrategier, hvor der skal tages hensyn til hver enkelt sygdom. Det medfører en anseelig mængde behandlinger for den enkelte (Smith et al. 2010; Shippe et al. 2012) og store samfundsmæssige omkostninger (Wolff et al. 2002; Glynn et al. 2011). Multisygdom forekommer også 
hyppigere blandt ældre, og det er i sig selv et voksende problem, fordi vi lever længere og længere, og andelen af ældre i befolkningen vokser. Sygehusforbruget er stigende og størst i de ældste aldersgrupper, og desto ældre man er, desto større er risikoen for kroniske sygdomme. I Danmark har over halvdelen af befolkningen over 65 år multisygdom (Larsen et al. 2013).

Mit projekt rammer dermed ind i en politisk og samfundsmæssig problemstilling. Det stigende antal patienter med multisygdom stiller nemlig det danske sundhedsvæsen, der i dag organisatorisk og fagligt er målrettet en specialiseret indsats rettet mod enkeltsygdomme, over for en stor udfordring i de kommende år (Reventlow et al. 2013). Multisygdom er både præget af og bidrager til social ulighed (Lawson et al. 2013), idet uligheden forstærkes desto flere samtidige sygdomme, man har (Barnett et al. 2012).

Med udgangspunkt i mit feltarbejde fremdrager jeg fire menneskers historier om et hverdagsliv med sygdom. De eksemplificerer, hvordan sundhed opfattes som et udefra defineret krav til en bestemt livsstil, som det ikke altid er muligt eller ønskeligt at efterkomme. Disse fire mennesker navigerer på forskellig vis i deres hverdag mellem på den ene side behandlingsplaner og mål, der er sat i samarbejde med fx lægen, og på den anden deres egen tilgang til, hvad der er vigtigt at prioritere; det kan være det spirituelle, familierelationer eller handle om at ,være glad“. Når behandlinger eller øvelser vælges fra, kan det imidlertid skabe forværring i de kroniske sygdomme, og det opfattes som noget negativt af systemet rundt om den enkelte: læge, kommune, hospital. I forlængelse af disse fire menneskers historier vil jeg vise, hvordan jeg ubevidst reproducerer denne forestilling, når jeg fx sidder over for Hans, der lider af kronisk obstruktiv lungelidelse (KOL) og når at ryge syv cigaretter under et af mine besøg på godt en time. Her har jeg skrevet i mine noter, at Hans virkelig ville få nemmere ved at røre sig, som han gerne vil, hvis han skruede ned for smøgerne.

\section{De usunde}

Forud for min diskussion af modsætningsforholdet mellem den sundhedstænkning, jeg repræsenterer i mit projekt, og de forståelser af sundhed, jeg møder hos informanterne, vil jeg introducere læseren til fire mennesker, som er både sunde og usunde - afhængigt af øjnene, der ser.

\section{Hans, den gamle købmand}

Hans er en 71-årig mand med tidligere alkoholmisbrug, diabetes, amputeret ben og KOL. Han er født og opvokset i en lille landsby på Lolland, men boede en del af sit voksenliv på Sjælland, indtil han blev skilt og flyttede tilbage. Hans er tidligere købmand og arbejdede i sin tid 70 timer om ugen og siger om sig 
selv, at han ,ikke er bange for at tage fat“. Han måtte holde op med at arbejde på grund af benet, men arbejder somme tider lidt „sort“ for en kammerat, hvor han kan sidde ned. Han bor alene i et lille hus, efter at hans hund blev aflivet af kommunen under hans sidste lange indlæggelse. Det, mener Hans, „nu også var det eneste rigtige at gøre", for han var der ikke til at tage sig af den. Hans ryger dagligt cirka 40 cigaretter og drikker fem-seks øl, men han rører ikke stærk spiritus mere. Han fortæller, at han tidligere havde et alkoholmisbrug, men nu har han det under kontrol. Familien ser han kun sjældent, men han har dagligt besøg af en veninde, og når vejret tillader det, tager han sin elscooter ned i den lokale klub. Ifølge Hans følger han sjældent lægens råd, og han har ikke lyst til at holde op med at ryge, men han tager sin medicin, som han skal. Det vigtigste for Hans er at opretholde en form for social status som en, der tjener sin egne penge og lever et frit liv uden hjælp. Hvis der bliver for meget fokus på sygdommene, „føles det, som om jeg bliver kastreret“. For Hans er den lille opsparing, han har, vigtig, fordi den giver ham råd til at kunne give en runde $\varnothing 1$ og betale veninden for at gøre rent - „for det er altså arbejde for kvindfolk““.

\section{Karin, kunstneren}

Hjemme hos Karin er der ild i pejsen næsten året rundt, og den røde huskat slænger sig dovent foran varmen. Karin er en 69-årig kvinde med Parkinsons, gigt og en mave-tarm-sygdom. Hun bor med sin mand i et istandsat bondehus og er meget engageret $i$ det lokale kulturliv. Tidligere var hun altid den, som lavede nye klubber og arrangerede udstillinger og ture, men nu er hendes sygdomme så fremskredne, at hun har måttet skære ned på aktiviteterne. Alligevel er hun samlingspunkt for lokallivet. Hun har styr på naboerne og ved, om nogen er syge. Ved flere lejligheder, mens Karin og jeg er ude til arrangementer sammen, oplever vi, at nogen ikke er mødt op, og Karin ringer til vedkommende med det samme, hvis nu han fx er faldet og ligger alene og har brug for hjælp. På den måde er Karin, på trods af fysiske begrænsninger, en tryghed for mange, og når vi møder de lokale, bliver der hilst hjerteligt. Karin er afhængig af at tage sin medicin til tiden, men glemmer det ofte. Når jeg spørger, hvorfor hun ikke sætter en alarm, så hun kan huske det, forklarer hun, at hun ikke vil lade sygdommen styre sit liv. Hendes Parkinsons forværres også af gigten, men hun laver ikke de øvelser, hun skal, fordi hun hellere vil prioritere de få timer i døgnet, hun har lidt energi, på sit barnebarn og sine kunstprojekter. Det, der fremstår som meget bevidste prioriteringer i forhold til sygdomme og hverdagsliv, bliver dog, når man kender Karin, til et billede af en kvinde, der gør sit bedste for at passe sygdommene, men ikke magter det hele på en gang. Karins sygdomme volder hende både sorg og stor angst, men hun føler ikke, at kommunen eller lægerne vil hjælpe hende, og hun er med egne ord „for stolt til at plage“. 


\section{Klaus, trompetisten}

Klaus serverer altid smørrebrød og „lidt godt til dessert“, når man er på besøg. Overalt i hjemmet hænger fotos af datteren, særligt indrammet står hun med studenterhue på reolen. Han forklarer stolt, at hun er den første i familien, der blev student. Klaus er 66 og døjer med forhøjet blodtryk, gigt, diabetes type 2 og noget „vrøvl“ med den ene arm. Under vores første interview forklarer han, at jeg nok ikke kan „bruge“ ham, for han er ikke rigtig syg. Jeg forklarer ham, at jeg faktisk er ligeglad med, hvilke sygdomme han har, og at det for mig mest handler om hverdag og sundhed, og så beslutter vi sammen, at han nok kan bruges. Jeg tror, det hjælper, at vi har samme forkærlighed for smørrebrød. Klaus er overvægtig, og han og konen spiser meget kage og „gammeldags dansk mad“. De bor med deres to hunde $i$ et stort hus $i$ en landsby omgivet af marker. Klaus gider generelt ikke lave de øvelser, lægen siger, han skal: „Det er jo altid godt at røre sig og få noget motion. Men det kniber sgu lidt med lysten og med tiden. Når man ikke har tid, så får man ikke gjort det, og når man ikke har lyst, så får man ikke tid.“ I stedet bruger Klaus sin tid på at spille i det lokale brassband, på hundene og på at være derhjemme med konen: „Jeg er jo sådan en, der godt bare kan lide at være hjemme." På trods af at Klaus går med hundene, lader hverken han eller lægen til at opfatte det som „,rigtig“ motion, når Klaus refererer deres samtaler. I stedet fortæller han, at han har lovet lægen at prøve at komme lidt til holdtræningen, de har talt om. Det går også fint de første par uger, men den starter kl. 18, og det er spisetid hjemme hos Klaus, så han ender med at droppe den. Både han og konen synes, at tidspunktet er vældig ubelejligt.

\section{Lille Benny, fabriksarbejderen}

„Lille Benny“, som han bliver kaldt, er en 78-årig mand med diabetes, tidligere blodprop i hjertet, dårlig fordøjelse og gigt. Han har tidligere haft „malerhjerne“, men det er ifølge ham selv væk nu. Han spiller også i det lokale brassband, hvor de andre tager hensyn til ham, men i mine observationer er han ikke rigtigt en del af gruppen. Han har svært ved at indgå i det sociale og står oftest alene lidt væk fra de andre. En gang imellem taler en af de andre til ham, og så svarer han, men ellers passer han sig selv. Han siger sjældent noget, men han og jeg opnår en særlig kontakt, da vi spiller samme instrument i brassbandet, jeg starter i som en del af feltarbejdet. Mange af vores interviews har lange passager om, hvilke numre vi skal spille, og hvad vi mener om dirigenten. Med tiden åbner Benny sig, og jeg får lov at komme hjem og besøge ham. Mine fordomme om enlige ældre mænd bliver gjort til skamme, da jeg træder ind i et velholdt og rent lille byhus, hvor Benny bor alene med sin hund i en større by på Lolland. Han har ingen børn, og ekskæresten „skred med genboen“ for fem år siden. Benny fortæller, at hun gerne ville have ham tilbage på et tidspunkt, men det ville han 
ikke: „Så er det noget andet med ham her [hunden], ham ved jeg, hvor jeg har.“ Benny gør alt, hvad han får at vide af lægen, at han skal, og han kan huske alle sine sygdomme i tal, altså, hvad hans blodtryk er og skal være osv. Benny har arbejdet som ufaglært hele sit liv og synes generelt ikke, han bliver taget seriøst af sundhedsvæsenet. Han ryger ikke og får daglig motion med hunden, ligesom han tager sin medicin, som lægen har foreskrevet.

Fælles for de fire mennesker, jeg her har trukket frem, er, som jeg har prøvet at fremstille i beskrivelsen af deres sygdomme og pasningen af dem, at de regnes for usunde eller dårlige til at passe på sig selv - i hvert fald ifølge „systemet", menneskeliggjort i de sundhedsprofessionelle, jeg mødte i projektets deltagerobservationer. Selv om Benny gør, hvad han skal, forstår han sjældent, hvad lægen siger, og det ligger til grund for mange misforståelser, som resulterer i en forværring af sygdommene. Også Hans' livsstil er usund ligesom Klaus', mens Karin primært burde være bedre til at passe på sig selv. Hvad de har tilfælles er også, at de, hvis man kigger på prioriteringer, og hvad der har betydning for dem i hverdagen, træffer nogle bevidste valg og har en høj selvoplevet livskvalitet. Deres ideer om sundhed handler om henholdsvis at kunne være sammen med „gutterne“, at fortsætte sit aktive kunstnervirke, at spise og hygge med konen og at være sig selv. Somme tider medfører det en nedprioritering af behandlinger, men jeg vil argumentere for, at det ikke nødvendigvis er usundt.

\section{Kan man studere sundhed?}

Der går ikke lang tid inde i feltarbejdet, før jeg får en dårlig smag i munden. Jeg kigger på behandlingsstrategier og egenomsorg, og når jeg fortæller om mit projekt, bliver jeg ofte spurgt af kolleger, hvorfor mine informanter mon ikke gør det rigtige, altså motionerer, spiser sundt, tager deres medicin korrekt, reagerer på symptomer osv. Beredvilligt svarer jeg, at de lollikker, jeg følger, faktisk har alle mulige former for ressourcer og træffer nogle valg, måske ufornuftige set fra en biomedicinsk synsvinkel, men fra deres egen synsvinkel velovervejede og pragmatiske egenomsorgsvalg. Sådan ser jeg det, indtil Hans en dag i sin tilrøgede stue siger til mig: „Altså, nu har jeg jo røget hele mit liv, så jeg kan ikke se, hvorfor det er så vigtigt at være så helvedes sund.“ I det øjeblik, med cigarlugt hængende i tøjet, går det op for mig, at mit forsøg på at forklare - måske endda forsvare - mine informanters sundhedsvalg stadig er en reproduktion af det moralske imperativ, der ligger $i$ at analysere sundhedsadfærd ud fra en dikotomisk tilgang, hvor noget er rigtigt, og andet er forkert. Hans' valg er ikke et udtryk for egenomsorg. Han gider bare ikke holde op med at ryge. 
Det er erfaringer som ovenstående, der danner baggrunden for mine etiske og moralske overvejelser. Hvordan navigerer jeg fx mellem ønsket om på den ene side at respektere Hans' autoritet og selvbestemmelse over eget liv og på den anden side bedrive forskning, der kan hjælpe Hans (og andre) til en bedre hverdag, så han ikke er så generet af sin KOL og måske kan komme lidt uden for lejligheden igen, som han så gerne vil? Dette bliver særlig problematisk, når jeg står med en konkret stillet opgave, der ikke er uafhængig af økonomiske og politiske styringer. Jeg finder således mig selv i et landskab af moralske imperativer, hvor kan/skal/vil bliver styrende i altruismens navn: I mit baghoved lyder det sundhedsfaglige argument, at de multisyge skal forbedre deres egenomsorg, for deres egen skyld.

Mit feltarbejde bliver altså et eksempel på, hvordan vi som antropologer færdes med både forpligtelser over for videnskabelige spilleregler og etiske fordringer om at optræde moralsk i forhold til de mennesker, vi studerer. Denne dualitet er bydende tvunget sammen af den antropologiske metode, der forudsætter både humanitær medleven og god videnskabelig praksis, et spændingsfelt, som den feltarbejdende antropolog må lære at leve i (Hastrup 2004a:419).

\section{Antropologen som oversætter}

Hej Kirsten, tak, fordi du vil hjælpe mig. Jeg mangler som sagt to kvinder til mit ph.d.-studie; de skal være over 65 og have mindst to kroniske sygdomme - gerne også en psykisk lidelse. Og så skal de selvfølgelig bo på Lolland! Jeg vil gerne have lov til at besøge dem derhjemme eller eventuelt snakke med dem et andet sted, hvor de føler sig trygge. Derefter regner jeg med at have jævnlig kontakt med dem, med besøg osv. det næste års tid. De kan naturligvis altid sige nej undervejs, hvis det bliver for meget. PS: Du må lokke dem med, at jeg har kage eller smørrebrød med, ha ha. Mange hilsner, Alexandra (Mail til lokal gatekeeper, juni 2015).

Ovenstående mail udstiller min naivitet, som jeg gradvist erkender, fordi jeg begynder at reflektere over min forestilling om informanterne. Antropologien baserer sig på, at der er en anden eller noget andet at studere, men det er et begreb, der er ladet med værdi og potentielt konfliktfyldt. I 1980'erne blussede repræsentationsdebatten op, foranlediget af et ønske om at frigøre sig fra skabelsen af andethed, idet der blev argumenteret for, at den etnografiske beskrivelse undertiden fratog folk deres egen stemme og tingsliggjorde dem (se fx Marcus \& Fischer 1986). Debatten fremhævede sprog som en opmærksomhedsfaktor, både fremmedsprog, modersmål og den tavse viden, der skal omsættes til ord af forskeren (Hastrup 2003:216). Løsningen synes ofte i dag at være en diskussion af forskerens positionering og overvejelser om repræsentation, men viden om 
den anden produceres stadig i en kontekst af tid, rum og politik (Fabian 2002), og vores fag, eller jeg selv i det mindste, har stadig en normativ forestilling om den anden, som man kan analysere sig frem til i min mail til Kirsten

Vil det så sige, at jeg slet ikke kan bruge det materiale, jeg har indsamlet? Nej, langtfra. Men det forudsætter en konstant refleksion over, hvordan og hvorfor mit empiriske objekt tager sig ud, som det gør, og hvilke konsekvenser det har. Litteraturteoretikeren G.C. Spivak argumenterer for, at viden aldrig kan være neutral, og at viden rummer bagvedliggende interesser. For Spivak betyder det blandt andet, at viden kan forstås som en eksportvare fra Vesten til resten af verden med den hensigt at opnå et (oftest) økonomisk udbytte. Hun viser således, at den svage anden kun har mulighed for politisk repræsentation gennem en intellektuel, og gør dem derved til subjekter uden reel mulighed for at kunne tale for sig selv (Spivak 1988). Spivak taler om de subalterne grupperinger i kolonisamfundet, men hvis vi følger præmissen om, at det er de intellektuelle, der har taleindflydelse i samfundet, efterlader det en stor gruppe mennesker uden reel mulighed for indflydelse - også i vores eget samfund. Det er måske en overmodig konklusion, men lad os lege med tanken: at repræsentation, også af lokal viden og narrativer, forudsætter en intellektuel „oversætter“:

Først så jeg, at de havde skrevet i Kulturrejser, et eller andet med, at de ikke ville have folk med, som ikke var selvhjulpne og kunne gå selv [...] Så tænkte jeg, at jeg lige ville gøre et lille forsøg, så skrev jeg til dem: 'Kære Kulturrejser-medarbejder. Jeg har været sådan og sådan afsted, og det har været spændende [...] Og det vil jeg meget gerne igen, men jeg kan ikke mere end sådan og sådan. Jeg kan kun gå med en stok eller min mand under armen. Han kan tage nogle lange ture, og jeg kan tage nogle korte ture, så kan jeg tage en taxa hjem, eller hvad jeg nu kan [...]' Så skrev de tilbage, at hvis jeg havde den holdning, så var jeg hjertelig velkommen. Det var da meget sødt. Så jeg må godt tage med, selv om jeg ikke kan gå. Det er fint nok ... Ja, nu får du den akutte krise (Karin, interview sommer 2015).

Karin, som taler her, er også dybt engageret $\mathrm{i}$ handicapforhold og vil meget gerne fortælle om sine erfaringer. Hendes pointe er, at folk, der ikke er så gode til at „råbe op“ som hende, ikke får nogen hjælp, og i den ovenstående historie vil hun illustrere, at man altså sagtens kan gøre ting, selv om man er syg. Den sidste sætning hentyder måske til, at hun forestiller sig, at jeg ikke finder det relevant, men at hun altså bare er nødt til at fortælle det, underforstået, at jeg måske kan fortælle andre om hendes erfaringer.

Et studie fra 1990 viser, at grupper eller individer med få videnskabelige eller sociale ressourcer pr. definition vil tiltrække forskere, mens personer med flere ressourcer vil have en tendens til at møde forskeren med en vis reservation eller mistro (Scott et al. 1990). Jeg vil mene, at interviewet med Karin vi- 
ser, at vi som forskere stadig skal være opmærksomme på risikoen for en fremstilling af vores informanter som en homogen, passiv anden. Dermed risikerer vi at indsnævre det analytiske potentiale i forskningen ved at skabe afgrænsede grupper og overse sammenhængen mellem grupperne og resten af samfundet (Olwig 2002). I forlængelse heraf bør vi også fjerne romantiseringen af eller trangen til at redde den anden. Antropologiens raison d'être må snarere være at undersøge, hvordan noget bliver defineret som et problem i det studerede samfund (Jöhncke 2003:29).

\section{Selvkritikken spirer}

Som feltarbejdet skrider frem, vokser min medleven i mine informanters liv og giver sig til kende $\mathrm{i}$ en tiltagende kritisk stillingtagen til det overordnede politiske fokus og opbakning til at sikre mere lighed og ,en ensartet folkesundhed“ (Region Sjælland 2016a). Efter en prøve med det lokale brassband har jeg noteret følgende:

Jeg ankommer til den største skole i Nakskov, hvor orkesteret øver. Dorte tager imod mig og undskylder, at der ser sådan ud. I underetagen er en nu lukket svømmehal, og bygningen bærer præg af slid og brug. Oppe i aulaen, der er af den gamle og fine slags med en god akustik, er orkestermedlemmerne ved at stille op. Med få undtagelser er de alle ældre mænd. Der er den sædvanlige brassbandjargon, som er hård og lummer, selv om de endnu ikke helt tør være så grove i mit nærvær. I pausen nævner jeg, at jeg gerne vil tale med nogen, som er syge og over 65 , og de griner og peger hinanden ud - det er nærmest alle. Carsten har kage med - det er hans tur - og vi drikker øl af flasken, mens vi spiser. Et par af de mænd, jeg har interviewet siden sidst, og som jeg ved har diabetes, siger nej tak til kagen så højt, at jeg ikke kan undgå at høre det. Det virker påtaget, især fordi jeg har set dem spise kage før uden overvejelser. Er det til min ære?

I mine møder med deltagerne har jeg ikke lagt skjul på, at jeg er der for at undersøge, hvilke sundhedsvalg man træffer, når man har mange kroniske sygdomme. Jeg har ikke italesat det som et fokus på syge og socialt udsatte, hvad det egentlig heller ikke er tænkt som, men ovenstående eksempel viser måske de overvejelser, det giver at sige ja til at medvirke i et sundhedsforskningsprojekt. Jeg vil mene, at min blotte tilstedeværelse i forskningsregi er medvirkende til at rammesætte nogle specifikke moralske handlerammer, som mine informanter så bevidst eller ubevidst navigerer i. De specifikke stereotyper af tilbageståenhed og usund livsstil, der forbindes med Danmarks landdistrikter, faciliterer nemlig skyldsspørgsmålet, der følger de multisyge. „Vi er nok ikke så gode til at passe på os selv hernede ... [sygdommene] er da nok min egen skyld," siger Ove på 72 om de kroniske 
sygdomme, han har udviklet de seneste ti år. Som jeg har vist, forstås flere af sygdommene af det offentlige danske sundhedsvæsen kausalt i sammenhæng med usund kost, rygning, overvægt, manglende motion og manglende sygdomsindsigt, og denne forklaringsmodel lader mine informanter til at have adopteret.

Som den danske antropolog Charlotte Baarts beskriver sin oplevelse af at gøre feltarbejde blandt alternative behandlere i Danmark, finder jeg også mig selv fanget mellem feltets sundhedsopfattelser og den biomedicinske som det sande regime (Baarts 2009:430). Og igen slår det mig - er jeg i gang med at indgå i en de facto partisk relation og gøre mine informanter til ,the underdog"? Baarts skriver, at kvalitative forskere altid er i et partisk forhold med "the underdog", altså den part som har færrest akademiske eller sociale ressourcer (op.cit.423). Selv om mine deltagere ikke nødvendigvis vil se sig selv som ressourcesvage, reflekteres deres position i samfundet i mødet med „overhunden“, i det følgende eksempel manifesteret i lægen:

Alexandra: Så man tror ikke altid på, hvad lægen siger?

'Lille Benny': Nej, ikke altid. Engang imellem føles det, som om de er ligeglade.

Alexandra: Prøv at forklare det!

'Lille Benny': Det er bare sådan noget, jeg føler. For eksempel nu her det sidste år ... fx da jeg arbejdede, der sov jeg ikke andet end fem-seks timer og stod op kl. 5 om morgenen og kørte på arbejde, men nu kan jeg da godt sidde om formiddagen og slumre lidt og kan godt falde i søvn, mens jeg sidder og læser avisen. Så jeg sagde, at jeg følte mig lidt træt en gang imellem. Så sagde han: 'Nå ja, men du skal også tænke på, hvor gammel du er.' Senere har jeg fået at vide, at det har noget at gøre med de indsprøjtninger, jeg får på Næstved Sygehus, men han sagde bare dét der.

Mens mit projekt i tråd med mange andre sundhedsantropologiske projekter startede som et klinisk anvendeligt studie, der med antropologisk indsigt skulle bidrage til løsning af kliniske, biomedicinske problemer (Rhodes 1996:165), bevæger jeg mig altså nu mere i retning af et kritisk medicinsk-antropologisk studie, hvor de politiske og økonomiske kræfter, der skaber det medicinske system og bestemmer karakteren og omfanget af dets virkninger, har min opmærksomhed.

Jeg ændrer bevidst min titel fra „medicinsk antropolog“, som jeg finder tæt knyttet til en biomedicinsk forståelsesramme, til det mere holistiske „sundhedsantropolog“". Ligeledes ændrer jeg i løbet af projektet den mundtlige omtale af deltagerne i projektet fra ,informanter" til ,samtalepartnere“, om end jeg her for overskuelighedens skyld stadig bruger betegnelsen ,informanter“. Ingen af begreberne er mine, jeg følger blot sundhedsantropologiens nyeste diskurser. Det er måske en lille dråbe i havet, men det er et sted at starte. 


\section{Empatisk vidensproduktion}

Trods ovenstående standpunkt kan jeg ikke sige mig fri for personligt at befinde mig dybt forankret i det biomedicinske videnssystem. Jeg tror oprigtigt på, at hvis gigtlægen har sagt til min informant, at mere motion vil mindske generne fra gigten, er det rigtigt:

På vej hjem fra interview med Klaus. Mens vi gjorde frokosten klar, fortalte han, at han ikke har lavet de øvelser, lægen har sagt, han skal, for han kan simpelthen ikke se, hvorfor det skulle hjælpe, og jeg tror måske, han føler, det er sådan lidt for yogaagtigt. Jeg prøvede at prikke lidt til ham, men han holder på, at han får den motion, han skal, når han går med hundene, selv om han jo ikke får rørt sin arm der, og jeg er ret sikker på, at det er en spilleskade [trompet] ligesom Peters (Feltnote, vinter 2016).

Ovenstående er indtalt efter besøg hos Klaus, der foruden forhøjet blodtryk og sukkersyge type 2 har noget gigtlignende i højre arm og skulder. Jeg tror stadig, at det vil hjælpe Klaus, hvis han laver sine øvelser. Men han gider ikke, og han har desuden ikke lyst til at holde med at spille, så han har bare affundet sig med, at „den arm er dårlig, sådan er det"“. Men det er lige netop pointen. Den empatiske vidensindsamling betyder ikke, at vi nødvendigvis må være enige med vores informanter. Tværtimod vil det ikke være etisk korrekt at tilsidesætte vores forskningsinteresser til fordel for vores informanters prioriteringer (Baarts 2009:431).

I stedet bør vi søge at finde veje til at tale om informantens interesser, mens vi bedriver etisk forsvarlig forskning. I mit studie af social ulighed i sundhed betyder det eksempelvis, at jeg fokuserer på organisatoriske årsager til og individuelle konsekvenser af social ulighed set $\mathrm{i}$ et samfundsperspektiv, samtidig med at jeg må have en opmærksomhed mod ikke at reproducere forestillinger om, hvad ressourcer er, eller hvem der er belastet socialt og sundhedsmæssigt i sin adfærd. I praksis vil der i enhver antropologisk analyse altid findes en implicit kontrast mellem det, de andre ved om sig selv og deres verden, og så den viden, der søges af antropologen (Hastrup 2004a:412). Mens jeg henviser til forskning om, hvor stor en byrde det kan være at have multisygdom, fortæller jeg informanternes historier om at have et godt liv „på trods“, om at føle sig overset og nedgjort af læger på grund af førtidspension, om ægteskabet, når der kommer en tredje partner i form af alvorlig sygdom osv.

\section{Konklusion}

Det har ikke været min hensigt med artiklen at ugyldiggøre sundhedsstudier eller tale imod at arbejde for større undersøgelser. Det er derfor væsentligt at 
understrege to forhold. For det første er social ulighed i sundhed et oplagt felt for antropologien som fag, fordi vi med vores blik for det partikulære skaber en langt mere kompleks forståelse af, hvad ulighed betyder. De eksisterende parametre på uddannelse og indkomst (se Sundhedsstyrelsen 2011) befrier vi fra forforståelser for i stedet at skabe viden om det enkelte menneskes indlejring i og bidrag til fællesskabet. Jeg mener altså, uanset den forudgående kritik af min egen skabelse af det analytiske og empiriske objekt, at et fokus på social ulighed, her i sundhed, er en forpligtelse, vi som antropologer bør tage på os og dermed bruge vores fag til at engagere os i verden. For det andet er det ikke mit ærinde at skabe berøringsangst over for politisk og moralsk ladede felter. Vores antropologiske praksis skaber og udvikler det konkrete sociale felt, der studeres. Det betyder, at den viden, vi producerer, ikke kun afdækker menneskers liv, men nogle gange indirekte griber ind i deres livsverden, blandt andet gennem udformning af interventioner og retningslinjer (Hastrup 2004a:419). Det gælder i lige så høj grad den anden vej, hvor dem, vi bedriver forskning på, skal forstås som aktivt handlende individer eller grupper, der lige såvel kan have en politisk eller økonomisk dagsorden, som de ønsker at fremme ved at medvirke i forskningen (Baarts 2009:425).

Med udgangspunkt i mit feltarbejde blandt ældre mænd og kvinder med multisygdom på Lolland har artiklen undersøgt modsætningsforhold i sundhedsforskning: Sundhed fremstilles moralsk befæstet, hvilket jeg ubevidst har reproduceret delvist, og det at udføre et studie som led i en større undersøgelse åbner for et modsætningsforhold mellem (her) sundhedstænkningens repræsentanter og de mennesker, der studeres. Artiklens argument er derfor, at forskeren skal forholde sig etisk til sådanne modsætningsforhold i studier af sundhed og sygdom.

Balancegangen mellem at blotlægge epistemologiske forskelle og praktisere antropologi, hvor studiet er forankret i biomedicinske forståelser, former den måde, vi gør feltarbejde på, og de spørgsmål, vi stiller vores informanter. Empatisk vidensproduktion er det vilkår, der kan skabe en mere nuanceret forståelse af biomedicinske begreber, fx multisygdom, når det forankres i en empirisk kontekst af hverdagsliv og patientoplevelser. Opgaven må være hele tiden at søge viden $\mathrm{i}$ takt med en stillingtagen til etik og selvrefleksion. Jeg har forsøgt at omforme fire menneskers historier og mine egne refleksioner til akademisk viden og håber at kunne pege på de underliggende logikker og organisatoriske forhold, der er med til at forme multisyges livsverdener. I erkendelse af ikke at kunne gøre det alene håber jeg, at min forskning vil bidrage til på sigt at kunne skabe bedre vilkår for at leve livet med kroniske sygdomme. Sund eller ej. 


\section{Noter}

Tak til temaredaktionen og reviewere for god, konstruktiv kritik, som har bidraget til at skærpe og teoretisere artiklens argumenter.

1. I de seneste år er der sket store ændringer i den voksne befolknings sygdomsmønstre. Med flere og bedre behandlinger er kroniske sygdomme ikke længere noget, man dør af, men noget, man lever med. Det betyder, at flere og flere mennesker lever med mindst to kroniske eller langvarige sygdomme; i skrivende stund regner man med cirka 30 procent af den voksne befolkning i Danmark (Larsen 2017). At have flere sygdomme på én gang komplicerer behandlingen og stiller store krav til den enkelte. For at kunne leve op til denne stigende sundhedsudfordring opererer mange medicinske og samfundsfaglige forskere med begrebet „,multisygdom“ (Frølich et al. 2017). Der findes forskellige definitioner; her i artiklen følger jeg den brede definition: mindst to kroniske eller langvarige sygdomme til stede samtidig hos en patient (van den Akker et al. 1996:69). Sygdommenes karakter er ikke afgørende her, idet det er mængden af behandlinger og uoverskueligheden i hverdagen, jeg her forholder mig til.

2. Projektet er udformet som et erhvervs-ph.d.-studie, der forløb i perioden 2014-2017. Foruden Innovationsfonden og Danske Patienter har også Forskningsenheden for Almen Praksis, Fonden for Almen Praksis, Helsefonden, Oticonfonden, Joseph Fox International Fellowship og Region Sjælland finansieret studiet på forskellig vis.

\section{Litteratur}

van den Akker, Marjan, Frank Buntinx \& J. André Knottnerus

1996 Comorbidity or Multimorbidity. What's in a Name. A Review of Literature.

European Journal of General Practice 2:65-70.

van den Akker, Marjan, Frank Buntinx, Job F.M. Metsemakers, Sjef Roos \& J. André

Knottnerus

1998 Multimorbidity in General Practice. Prevalence, Incidence, and Determinants of Co-Occurring Chronic and Recurrent Diseases. Journal of Clinical Epidemiology 51(5):367-75.

Baarts, Charlotte

2009 Stuck in the Middle. Research Ethics Caught Between Science and Politics.

Qualitative Research 9(4):423-39.

Barnett, Karen, Stewart W. Mercer, Michael Norbury, Graham Watt, Sally Wyke \& Bruce Guthrie

2012 Epidemiology of Multimorbidity and Implications for Health Care, Research, and Medical Education. A Cross-Sectional Study. The Lancet 380(9836):37-43.

Brown, Peter \& Marcia Inhorn

1996 Disease, Ecology and Human Behavior. In: T. Johnson \& C. Sargent (eds):

Medical Anthropology. Contemporary Theory and Method. Pp. 187-214. Westport, CT: Praeger.

Davis, Michael

2010 Bringing Ethics up to Date? A Review of the AIATSIS Ethical Guidelines.

Australian Aboriginal Studies 2:10-21.

Erhvervsstyrelsen

2016 Definition af yderområder. https://regionalt.erhvervsstyrelsen.dk/definition-afyderomraader. 
Fabian, Johannes

2002 [1983] Time and the Other. How Anthropology Makes its Object. New York: Columbia University Press

Foucault, Michel

1979 [1976] The History of Sexuality Volume 1. An Introduction. London: Allen Lane.

1988 Technologies of the Self. In: L. Martin, H. Gutman \& P.H. Hutton (eds):

Technologies of the Self. A Seminar with Michel Foucault. Pp. 16-50. Amherst:

University of Massachusetts Press.

Frølich, Anne, Frede Olesen \& Inge Kristensen

2017 Introduktion og generelle forhold. I: A. Frølich, F. Olesen \& I. Kristensen (red.): Hvidbog om multisygdom. Dokumentation af multisygdom i det danske samfund - fra silotænkning til sammenhæng. Side 15-17. Virum: TrygFonden.

Glynn, Liam G., Jose M. Valderas, Pamela Healy, Evelyn Burke, John Newell, Patrick Gillespie \& Andrew W. Murphy

2011 The Prevalence of Multimorbidity in Primary Care and its Effect on Health Care Utilization and Cost. Family Practice 28(5):516-23.

Hastrup, Kirsten

2003 Sproget. I: K. Hastrup (red.): Ind i verden. En grundbog i antropologisk metode. Side 207-27. København: Hans Reitzels Forlag.

2004a Refleksion. Vidensbegreber og videnskab. I: K. Hastrup (red.): Viden om verden. En grundbog i antropologisk analyse. Side 409-25. København: Hans Reitzels Forlag.

2004b Getting it Right. Knowledge and Evidence in Anthropology. Anthropological Theory 4(4):455-72.

2013 Vi bebor mangfoldige verdener - eller? Imod udsagnet. Tidsskriftet Antropologi 67:41-47.

Højbjerg, Christian Kordt

2013 Den „ontologiske vendings“ utilstrækkelighed. Imod udsagnet. Tidsskriftet Antropologi 67:29-34.

Høstrup, Helle \& Alexandra Ryborg Jønsson

2017 Livet skal leves, mens man har det. I: A. Frølich, F. Olesen \& I. Kristensen (red.): Hvidbog om multisygdom. Side 21-27. Virum: TrygFonden.

Jöhncke, Steffen

2003 I den gode sags tjeneste? Om antropologi, stofbrugere og lodrette forbindelser.

Tidsskriftet Antropologi 45:29-47.

Kaufman, Sharon \& Lakshmi Fjord

2011 Medicare, Ethics, and Reflexive Longevity. Governing Time and Treatment in an Aging Society. Medical Anthropology Quarterly 25(2):209-31.

Kleinman, Arthur

1995 Writing at the Margin. Discourse between Anthropology and Medicine. Berkeley: University of California Press.

Larsen, Finn Breinholt

2017 Multisygdom - hvad er problemet? I: A. Frølich, F. Olesen \& I. Kristensen (red.): Hvidbog om multisygdom. Side 27-35. Virum: TrygFonden. 
Larsen, Finn Breinholt, Karina Friis, Mathias Lasgaard, Marie Hauge Pedersen, Jes Bak Sørensen, Louise Margrethe Arildsen Jakobsen \& Julie Christiansen

2013 Hvordan har du det? Sundhedsprofil for regioner og kommuner. Region Midtjylland: Center for Folkesundhed.

Lawson, Kenny, Stewart Mercer, Sally Wyke, Eleanor Grieve, Bruce Guthrie, Graham Watt \& Elisabeth Fenwick

2013 Double Trouble. The Impact of Multimorbidity and Deprivation on PreferenceWeighted Health Related Quality of Life a Cross Sectional Analysis of the Scottish Health Survey. International Journal for Equity in Health 12:67.

Marcus, George \& Michael Fischer

1986 Anthropology as a Cultural Critique. An Experimental Movement in the Human Sciences. Chicago: University of Chicago Press.

Nöel, Polly Hitchcock, B. Chris Frueh, Anne C. Larme \& Jacqueline Pugh

2005 Collaborative Care Needs and Preferences of Primary Care Patients with Multimorbidity. Health Expectations 89:54-63.

Olwig, Karen Fog

2002 The Ethnographic Field Revisited. Towards a Study of Common and not so Common Fields of Belonging. In: V. Amit (ed.): Realizing Community. Concepts, Social Relationships and Sentiments. Pp. 124-45. London: Routledge.

Oxlund, Bjarke \& Susan Whyte

2014 Measuring and Managing Bodies in the Later Life Course. Journal of Population Ageing 7(3):217-30.

Region Sjælland

2016a Broen til Bedre Sundhed. http://www.regionsjaelland.dk/Kampagner/broen-tilbedre-sundhed/Sider/default.aspx

2016b Lolland Falster er mulighedernes land. http://www.regionsjaelland.dk/nyheder/ Sider/Lolland-og-Falster-er-mulighedernes-land.aspx.

Reventlow, Susanne, Jakob Kragstrup, Ann Dorrit Guassora, Lars Bjerrum \& Niels de Fine Olivarius

2013 Multimorbiditet $\mathrm{i}$ et sundhedsvæsen, som er indrettet til enkeltsygdomme. Ugeskrift for Læger 175(16):1093.

Rhodes, Lorna Amarasingham

1996 Studying Biomedicine as a Cultural System. In: T. Johnson \& C. Sargent (eds):

Medical Anthropology. Contemporary Theory and Method. Pp. 159-173. Westport, CT: Praeger.

Sausdal, David \& Henrik Vigh

2013 Den ontologiske blænding. Om den ontologiske vendings metodiske og politiske problemer. Tidsskriftet Antropologi 67:101-21.

Scott, Pam, Evelleen Richards \& Brian Martin

$1990 \quad$ Captives of Controversy. The Myth of the Neutral Social Researcher in Contemporary Scientific Controversies. Science, Technology and Human Values 15(4):474-94.

Shippee, Nathan, Nilay Shah, Carl May, Frances Mair \& Victor Montori

2012 Cumulative Complexity. A Functional Patient-Centered Model of Patient Complexity Can Improve Research and Practice. Journal of Clinical Epidemiology 65(10):1041-51. 
Smith, Susan, Siobhan O'Kelly \& Tom O'Dowd

2010 GPs' and Pharmacists' Experiences of Managing Multimorbidity. A “Pandora's box". British Journal of General Practice 60(576):285-94.

Sparrow-Simpson, William John

1919 The Letters of St. Augustine. London: Society for Promoting Christian Knowledge. New York: Macmillan.

Spivak, Gayatri C

1988 Can the Subaltern Speak? In: C. Nelson \& L. Grossberg (eds): Marxism and the Interpretation of Culture. Pp. 271-313. Basingstoke: Macmillan.

Sundhedsstyrelsen

$2011 \quad$ Ulighed i sundhed. Årsager og indsatser. http://www.sst.dk/ /media/F674C77308F B4B0CA00EB038F17E239B.ashx.

Svendsen, Mette Nordahl

2009 Kritisk engageret videnskab. Erfaringer fra forskning om gen- og forplantningsteknologierne. Tidsskrift for Forskning i Sygdom og Samfund 10:37-57.

Tinetti, Mary E., Gail J. McAvay, Sandy S. Chang, Anne B. Newman, Annette L. Fitzpatrick, Terri R. Fried \& Peter N. Peduzzi

2011 Contribution of Multiple Chronic Conditions to Universal Health Outcomes. Journal of the American Geriatrics Society 59(9):1686-91.

Wolff, Jennifer L., Barbara Starfield \& Gerard Anderson

2002 Prevalence, Expenditures, and Complications of Multiple Chronic Conditions in the Elderly. Archives of Internal Medicine 162(20):2269-76.

Ørtenblad, Lisbeth, Alexandra Ryborg Jønsson \& Lucette Meillier

$2015 \quad$ Komplekse liv. Patientinddragelse som vej til et bedre hverdagsliv for multisyge? Tidsskrift for Forskning i Sygdom og Samfund 22:83-101. 
